\section{National Institutes of Health sets up its own bioethics panel}

[WASHINGTON] The US National Institutes of Health (NIH) has set up a committee to coordinate responses to new ethical issues and to anticipate future quandaries. The initiative comes at the end of a year that has seen heated public disputes about cloning and the use of placebos in AIDS-related trials in developing countries, and the breach of an embryo research ban.

The Trans-NIH Bioethics Committee was established this autumn on the orders of Harold Varmus, the NIH director, partly in response to a recommendation by an advisory panel that an NIH-wide committee should deal with ethical issues related to genetics (see Nature 385, 756; 1997).

But Varmus decided to make the committee's mandate broader. He felt "it was important to have substantive and frequent internal discussions on ethical, legal and social issues, so that we would be less reactive and more proactive," says Lana Skirboll, NIH deputy director for science policy, who chairs the committee.

The committee comprises senior staff representatives from each NIH institute, centre and division, and has more than 30 members. It meets privately once a month and at its three meetings so far it has discussed the capacity of the mentally ill to consent to participation in research, and medical records privacy. Future topics will include xenotransplantation and the ethical use of stored tissue samples.

A subcommittee of the new body is drafting recommendations in a 'white paper' on the confidentiality of research records and patient access to them. Expected in draft form next month, the paper will be circulated for advice and comment to scientists and patients' advocates. Ultimately, the committee hopes it will influence Congress, which is due to draft a privacy law by 1999 .

But the white paper is an exception, says Skirboll. In general, she says, the committee's role is not to formulate policy but to flag issues that need attention from all parts of $\mathrm{NIH}$, and "to keep ourselves on board with what's going on". Then, she says, "when we need to develop NIH-wide consensus, there is a forum in which to begin that discussion."

Skirboll cites growing public interest in bioethics as the reason why the NIH has moved now to establish an ethics committee (see Nature389, 658-663, 1997).

NIH has launched separately a department of clinical bioethics at the Warren Magnuson Clinical Center on the NIH campus in Bethesda, Maryland. The department will start with a budget of $\$ 500,000$ and five permanent staff.

Meredith Wadman

\title{
Energy labs urged to boost supercomputing capability
}

[WASHINGTON] A new integrated strategy for high-performance computing and simulation for the national laboratories funded by the US Department of Energy has been proposed by the department's senior scientific administrator.

Ernie Moniz, the new under-secretary of energy, last week told a meeting of the Laboratory Operations Board - a group of department officials, laboratory directors and outside experts set up to oversee management reforms at the labs - that a new approach is needed to give scientists at the laboratories access to the best hardware and software for computer-intensive problems.

Moniz, who chaired the physics department at the Massachusetts Institute of Technology before joining the government last month, believes that the department's non-weapons laboratories need to take an approach to supercomputing parallel to the \$500-million-a-year Accelerated Strategic Computing Initiative (ASCI) under way at the nuclear weapons laboratories.

The directors of the non-weapons laboratories are intensely jealous of ASCI, and have been fighting without success for better access to both the hardware it will buy and the knowledge of computational science it is expected to yield.

Many computer codes used by the scientists at present, Moniz says, "are developed in a rather isolated environment, without the benefit of advanced software engineering".

Some of the department's main research tasks could benefit, Moniz says — including the simulation of combustion in car engines, development of global climate models, hydrogeological studies for nuclear waste clean-up, and the processing of data from particle accelerators. "This kind of problemdriven approach to solving simulation problems is something the laboratories should be doing and, frankly, I don't see who else will do it," he told the board.

Moniz has asked officials to report early in the new year on the laboratories' computing and simulation needs and how they could best be met. Options could include wider use of ASCI machines for nonweapons-related work.

"I'd like to see an integrated approach across the department," says Moniz. Martha Krebs, assistant secretary for energy research, and Vic Reis, assistant secretary of defence programmes, have been "in dialogue" on the issue, he adds.

But Reis, who gets his money from the national security budget, has been reluctant to share ASCI facilities with other laboratories. Directors of the non-weapons labs have told Moniz they feel unfairly excluded from ASCI. "They have [said that], but it is changing," Moniz says. "We're not where we'd like to be yet, but I believe that Defense Programs is opening up significantly because of the changed nature of its mission."

But some officials say that Moniz may find it harder than he thinks to integrate anything across the fractious laboratory complex, as the web of connections between the laboratories and politicians makes it difficult for the energy department to administer them as a coherent group.

ColinMacilwain

\section{New Zealand imports technology foresight}

[SYDNEY] New Zealand's new government has launched a major effort to set priorities for public investment in science and technology. The exercise will use 'technology foresight' techniques, developed in Britain, Australia and Finland, to sketch out desirable futures, identify targets and develop strategies for achieving coveted goals.

Launching the project last week as one of her first acts as Prime Minister, Jenny Shipley acknowledged that New Zealand's "ability to create and use knowledge will outstrip physical resources as this country's source of wealth". New Zealand's economy has always in the past been dependent on exports of products from its fertile land. The project will be carried out through the Ministry of Research, Science and Technology, and will aim to decide public funding allocations for 2000 to 2002.

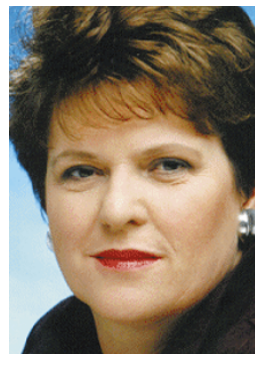

Maurice Williamson, the minister for research, science and technology, was promoted in rank to eighth place in the reshuffled cabinet. He said New Zealand needs to "identify the tools and resources

Shipley: 'knowledge is a key to wealth'. required to have a competitive advantage in the knowledge age".

Williamson's ministry provides policy advice, and is separate from funding authorities. Helen Anderson, the ministry's new chief scientific adviser, says the project followed a weekend retreat by 40 "leading thinkers" who considered possible scenarios for New Zealand up to 2010.

Peter Pockley 